\title{
Implementasi Kebijakan Transaksi Non Tunai Pemerintah Daerah di Indonesia
}

\author{
Astri Tania Herlen*, Vima Tista Putriana, Denny Yohana \\ Fakultas Ekonomi Pascasarjana Akuntansi, Universitas Andalas, Indonesia \\ ${ }^{*}$ Correspondence email: astritania127@gmail.com
}

\begin{abstract}
Non cash transactions are a new paradigm in the management of government finance. Non cash transactions are implemented in line with the issuance of the Minister of Home Affairs circular No. 910/1866 in 2017 concerning the implementation of non cash transactions in local governments. This is in accordance with the provisions of Presidential Instruction No. 10 in 2016. The purpose of this study is to investigate the application of non cash transactions by local governments in Indonesia. The results showed that the implementation varies across local governments in Indonesia in terms of when local governments under studied began to implement the system, minimum amount or threshold for the cash transactions allowed by the local governments under studied and types of transactions that have been done under non-cash transactions. The implementation of the non cash system is carried out in accordance with the principles of good governance. This non cash transaction system provides several benefits and constraints in implementing it in local governments.
\end{abstract}

Keywords: non cash; government.

\section{PENDAHULUAN}

Dalam rangka mewujudkan tata kelola pemerintahan yang lebih baik atau good governance, berbagai kebijakan telah dikeluarkan oleh pemerintah. Salah satu kebijakan tersebut adalah Gerakan Nasional Non Tunai (GNNT). GNNT mulai diperkenalkan oleh Bank Indonesia pada tahun 2014. Kebijakan ini bertujuan untuk dapat meningkatkan kesadaran dari masyarakat, pelaku bisnis serta lembaga-lembaga pemerintah untuk dapat menggunakan sarana pembayaran non-tunai dalam melakukan transaksi keuangan yang tentunya lebih mudah, aman dan efisien, sehingga secara perlahan akan terwujud cashless society.

Pada konteks pemerintah daerah, kebijakan nontunai pertama kali di uji cobakan di Pemerintah provinsi DKI pada tahun 2014 dan menjadi pionir dalam transaksi non-tunai di pemerintahan. Provinsi Jakarta konsisten dalam penerapan sistem non-tunai dan terus melakukan perkembangan, sehingga Gubernur Bank Indonesia menunjuk Jakarta sebagai model percontohan dalam penggunaan transaksi non-tunai (Petriella, 2014). Tahun 2018, seluruh pemerintah daerah di Indonesia diharapkan telah mengadopsi kebijakan ini dengan dikeluarkannya Surat Edaran Menteri Dalam Negeri Nomor 910/1867/SJ tentang implementasi transaksi nontunai pada pemerintah daerah kabupaten/kota.

Paper ini bertujuan untuk mendeskripsikan keberagaman implementasi kebijakan non-tunai pada pemerintah daerah di Indonesia. Penelitian ini menunjukan bahwa kebijakan non-tunai diterapkan secara beragam di seluruh Indonesia. Dimana pada hasil penelitian menunjukkan bahwa waktu penerapan sistem non-tunai berbeda-beda pada setiap pemerintah daerah dimulai dari sebelum tahun 2018 hingga tahun 2020. Pada penerapan sistem ini tidak semua transaksi langsung dapat dilakukan dengan cara non-tunai. Sistem ini dilakukan secara bertahap sehingga pada pelaksanaannya masih dapat ditemukan transaksi tunai dengan nominal tertentu.

Paper ini berkontribusi pada literatur di bidang Administrasi Publik dan Keuangan Daerah dengan menggambarkan bagaimana sebuah kebijakan publik di implementasikan oleh daerah dengan kondisi kesiapan yang berbeda-beda. Paper ini ditulis dengan struktur sebagai berikut. Bagian pertama adalah pendahuluan. Bagian kedua berfokus pada pembahasan kebijakan nontunai. Bagian ketiga menjabarkan metodologi penelitian. Bagian empat menampilkan hasil dan selanjutnya kesimpulan.

\section{Kebijakan Non Tunai}

Non-tunai merupakan sistem pembayaran digital tanpa menggunakan uang fisik (uang kertas atau uang logam). Sistem pembayaran dengan non-tunai atau tanpa uang fisik ini tidak dirancang untuk menggantikan sistem pembayaran tunai, tapi untuk saling melengkapi satu sama lain (nontunai.com). Alat pembayaran non-tunai atau uang giral biasa digunakan untuk melakukan pembayaran transaksi yang berjumlah besar sehingga lebih efisien dibandingkan pembayaran dengan uang kartal.

Di beberapa negara penggunaan transaksi dengan cara non-tunai lebih tinggi. Tee dan Ong (2016) menyebutkan di negara Uni Eropa yaitu Austria, Belgia, Prancis Jerman dan Portugal transaksi online dan penggunaan kartu debit dapat dianggap lebih mudah sebagai pengganti uang tunai dalam transaksi pembayaran. Indonesia mulai menerapkan sistem transaksi non-tunai tahun 2014 seperti yang telah disebutkan bagian pendahuluan. Bank Indonesia berharap sistem transaksi non-tunai dapat diterapkan disektor pemerintah di Indonesia. 
Hal ini didukung oleh Presiden dengan adanya Instruksi Presiden Nomor 10 Tahun 2016 tentang aksi pencegahan dan pemberantasan korupsi. Adanya Kebijakan non-tunai ini diharapkan dapat memberikan informasi yang lebih transaparan pada Pemerintah, dimana kegiatan ini dilakukan melalui media elektronik dengan menggunakan internet sehingga setiap transaksi pembayaran yang dilakukan oleh pemerintah lebih mudah untuk dilacak dan lebih mudah untuk ditemui apabila terjadi kecurangan dalam pemerintahan suatu daerah.

Menteri Dalam Negeri juga mendukung kegiatan non-tunai ini dengan dikeluarkannya Surat Edaran Menteri Dalam Negeri Nomor 910/1866/SJ pada tanggal 17 April 2017 tentang implikasi transaksi non-tunai pada Pemerintah Daerah provinsi dan Nomor 910/1867/SJ pada tanggal 17 April 2017 tentang implementasi transaksi non-tunai pada Pemerintah Daerah kabupaten/kota. Penerapan transaksi non-tunai merupakan suatu upaya pemerintah dalam meningkatkan pengelolaan keuangan daerah.

\section{Kebijakan Non Tunai dan Pengendalian Intern}

Salah satu manfaat dari penerapan transaksi nontunai adalah pengendalian internal pengelolaan pada kas meningkat. Apabila kewenangan daerah dalam menetapkan kebijakan implementasi transaksi non-tunai dilakukan semaksimal mungkin, tentunya akan tercipta suatu prosedur pembayaran non-tunai yang terotorisasi dengan baik dan terdokumentasi dengan jelas. Jika daerah mau dan mampu mengembangkan lebih lanjut, seperti dengan membangun aplikasi-aplikasi yang dibutuhkan maka terwujudlah sistem evaluasi, monitoring realisasi anggaran pembangunan dan pengadaan barang dan jasa dan juga transaksi keuangan dapat dipantau secara otomatis atau secara online oleh pimpinan.

Setiap data dari biaya yang telah dikeluatkan dicatat dengan jelas dan kinerja yang dilakukan juga jelas maka biaya-biaya yang diperlukan dapat diestimasi dan dikalkulasi secara cermat. Sebagai contohnya besaran biaya yang dibutuhkan untuk meningkatkan nilai sektor perternakan, besaran biaya yang dibutuhkan meningkatkan kesehatan, besaran biaya yang dibutuhkan untuk meningkatkan mutu pendidikan sekitar dan lainlainnya. Selanjutnya, data-data tersebut dapat dibandingkan dan dianalisis, apakah organisasi semakin efektif dan efisien, atau malah sebaliknya (Palantabirokrasi, 2017). Maka dari itu, sistem transaksi non-tunai lebih meningkatkan pengendalian dalam pengelolaan keuangan daerah karena apabila terjadi selisih antara anggaran yang telah ditetapkan dengan capaian kegiatan yang dilakukan dapat ditelusuri dengan jelas. Selisih tersebut dapat diidentifikasi lebih awal.

\section{Kebijakan Non Tunai dan Akuntabilitas Pengelolaan Keuangan Daerah}

Tidak hanya meningkatkan pengendelian intern pemerintah, transaksi non-tunai ini juga diharapkan dapat menghasilnya laporan keuangan yang akuntabilitas. Akuntabilitas keuangan daerah merupakan kewajiban pemerintah untuk dapat mempertanggungjawabkan pengelolaan keuangan daerah dan pelaksanaan kebijakan untuk mencapai tujuan yang telah ditetapkan serta dapat dipertanggung jawabkan secara periodik. Penerapan sistem transaksi non-tunai memiliki peran dalam meningkatkan akuntabilitas kinerja manajerial suatu organisasi.

Yudhanti (2018) dalam penelitiannya juga menyatakan bahwa transaksi non-tunai meningkatkan akuntabilitas keuangan pemerintah. Hal ini dikarenakan sistem transaksi pembayaran non-tunai didukung dengan adanya sistem informasi yang terintegrasi akan mencatat transaksi secara real time dan akurat yang dapat membuat operasional perusahaan semakin efektif dan efisien, sehingga dapat meningkatkan akuntabilitas.

Sistem transaksi non-tunai ini dapat meningkatkan akuntabilitas yang dapat dilihat dengan penggunaan APBD yang tepat sasaran, karena seluruh aliran dana dapat ditelusuri dan hasil akhir saldo perhitungan dalam pencatatan sama dengan saldo yang ada dalam rekening dan secara berkala akan tersaji didalam sistem dengan bukti pertanggung jawaban yang jelas. Hal ini sesuai dengan penelitian yang dilakukan oleh Dona (2018) dinyatakan bahwa akuntabilitas keuangan di sekretariat daerah Sumatera Barat menjadi lebih baik dengan adanya sistem non-tunai ini. Dimana segala bentuk transaksi keuangan dilakukan dengan menggunakan Cash Management System (CMS) yang bekerja sama dengan Bank Nagari. Sehingga untuk setiap pengeluaran yang dilakukan bendahara dapat dilihat dan ditelusuri untuk setiap kejadian transaksi. Tidak hanya itu, sistem non-tunai ini juga lebih memudahkan kinerja bendahara dalam hal bertransaksi.

\section{Kebijakan Non Tunai dan Transparansi Pengelolaan Keuangan Daerah}

Tidak hanya meningkatkan akuntabilitas, dengan adanya transaksi non-tunai ini juga berdampak pada transparansi pengelolaan keuangan daerah. Transparansi merupakan keterbukaan pemerintah daerah dalam membuat kebijakan keuangan daerah sehingga dapat diketahui dan diawasi oleh DPRD dan masyarakat. Transparansi pengelolaan keuangan daerah pada akhirnya akan menciptakan hubungan horizontal antara pemerintah daerah dengan masyarakat sehingga tercipta pemerintah daerah yang bersih, efektif, efisien, akuntabel dan responsif terhadap aspirasi dan kepentingan masyarakat. Prinsip keterbukaan yang memungkinkan masyarakat untuk mengetahui dan mendapatkan akses informasi seluas-luasnya tentang keuangan daerah. 
Transparansi ini hal yang paling utama yang dapat dilihat saat mentransfer dana ke stakeholder. Dona (2018) menyatakan bahwa dengan adanya sistem non-tunai ini pengelolaan keuangan saat ini secara tidak langsung sudah diketahui oleh publik, dikarenakan setiap transaski keluar masuk uang yang melalui APBD sudah berupa non-tunai dan sudah menggunakan sistem online berbasis perbankan. Pernyataan tersebut sama dengan penelitian yang dilakukan oleh Hendrawan dkk (2019) yang menyatakan bahwa dengan adanya transaksi nontunai, segala jenis transfer dapat dipantau secara real time untuk kepentingan audit serta telah terciptanya kesesuaian antara pelaporan buku kas umum dengan laporan rekening bank berdasarkan internet banking atau mobile banking.

Pelaksanaan transaksi keuangan daerah secara non-tunai, apabila diterapkan dengan baik maka akan menghasilkan laporan keuangan yang transparan. Adanya perubahan sistim dari tunai ke non-tunai ini, berarti telah ada upaya dari pemerintah dalam memperbaiki sistim yang ada ke arah yang lebih baik untuk mewujudkan tata kelola pemerintah yang baik tentunya.

\section{Kebijakan Non Tunai dan Good Governance}

Pengelolaan pemerintahan yang baik tentu menjadi tujuan dari semua pemerintah yang ada di Indonesia untuk dapat membangun daerah dan mensejahterakan rakyatnya. Adanya kebijakan non-tunai merupakan gebrakan yang dilakukan oleh pemerintah untuk dapat memudahkan dalam pengawasan keuangan daerah. Hal ini sejalan dengan tujuan untuk membangun daerah yang Clean and Good Governance.

Good governance menurut World Bank (1992) adalah suatu penyelenggaraan manajemen pembangunan yang solid dan bertanggungjawab yang sejalan dengan prinsip demokrasi dan pasar yang efisien, penghindaran salah alokasi dana investasi, dan pencegahan korupsi baik secara politik maupun administratif, menjalankan disiplin anggaran serta penciptaan legal dan political framework bagi tumbuhnya aktivitas usaha. Good governance tidak dapat terlepaskan dari prinsip-prinsip dasar penyelenggaraan pemerintahan yang baik, yaitu transparansi, partisipasi, dan akuntabilitas sebagai unsur utama (Raharja dan Hafrida, 2017).

Dengan didukungnya kebijakan transaksi nontunai pada pemerintah daerah, merupakan suatu upaya pemerintah untuk mewujudkan peningkatan efisiensi dan optimalisasi penerimaan daerah, serta mendorong efektivitas pengelolaan dana pemerintah daerah. Terwujudnya hal ini tentu berkaitan dengan terwujudnya good governance pada pemerintah. Kurnia (2020) dalam penelitian menyatakan bahwa penerapan transaksi nontunai dapat meningkatkan good governance terutama pada prinsip akuntabilitas, transparansi, efektivitas dan efisiensi. Dimana dalam pelaksanaan belanja pemerintah dapat menekan tingkat penyelewengan anggaran terutama korupsi. Sama halnya dengan penelitian yang dilakukan oleh Septiani dan Endah (2019) yang menyatakan bahwa penerapan transaksi non-tunai dalam pelaksanaan belanja pemerintah daerah sangat membantu dalam mewujudkan prinsip good governance terutama dalam mewujudkan prinsip akuntabilitas, transparansi, efektivitas dan efisiensi. Adanya transaksi non-tunai ini diharapkan dapat meningkatkan hubungan antara pemerintah, pihak swasta dan masyarakat. Transaksi non-tunai dinilai ini sangat membantu dalam mewujudkan prinsip good governance dalam menekan tingkat jumlah korupsi di pemerintah daerah.

\section{METODE}

Penelitian ini merupakan penelitian kualitatif, yaitu jenis penelitian documentary analysis. Implementasi kebijakan non-tunai pada pemerintah daerah di Indonesia akan dianalisa melalui berbagai dokumen yang terkait dengan implementasi kebijakan non-tunai. Total terdapat 9 Provinsi, 36 Kabupaten dan 28 Kota di seluruh Indonesia yang dianalisa. Penelitian ini menggunakan data sekunder berupa dokumendokumen terkait dengan implementasi kebijakan nontunai di berbagai pemerintah daerah di Indonesia. Keywords yang digunakan saat searching di mesin pencari Google adalah "implementasi transaksi nontunai di pemerintah", "penerapan transaksi non-tunai pemerintah", "kebijakan non-tunai pemerintah", "sosialisasi transaksi non-tunai pemerintah", "peraturan gubernur, bupati dan walikota tentang transaksi nontunai". Terdapat 23 Peraturan Daerah, 16 website resmi pemda dan 44 berita online yang dikumpulkan dalam penelitian ini. 83 dokumen yang digunakan dalam penelitian, kemudian dianalisa dengan menggunakan thematic analysis. Artinya, data dikelompokan berdasarkan tema yang muncul dalam penelitian ini. Terdapat 3 tema utama yang didefinisikan dalam penelitian ini yaitu: variasi, tantangan dan manfaat. Tema variasi merujuk pada variasi atau keragaman implementasi kebijakan non-tunai yang dilihat dari berbagai aspek seperti saat mulainya implementasi nontunai, jumlah transaksi yang telah di-non-tunaikan, batasan nilai transaksi yang masih diizinkan untuk transaksi tunai, perspektif lokasi: pemda Jawa/Bali dan Luar Jawa/Bali. Tema tantangan merujuk pada apa saja tantangan, kesulitan atau kendala yang dihadapi pemda dalam implementasi kebijakan non-tunai. Terakhir, tema manfaat merujuk pada apa saja manfaat yang dirasakan oleh pemda dengan implementasi non-tunai.

\section{HASIL DAN PEMBAHASAN \\ Implementasi Kebijakan Non Tunai Pada Pemerintah Daerah Di Indonesia}

Dalam mengimplementasikan kebijakan transaksi non-tunai, terdapat beberapa pihak atau stakeholders yang terlibat di dalamnya, yaitu: Bank Indonesia, Pemerintah Pusat, Pemerintah Daerah, Bank Partner, 
rekanan dan masyarakat. Penelitian ini dilakukan pada 73 pemerintahan di Indonesia. Penerapan sistem non-tunai berbeda-beda antara satu pemerintah daerah dengan pemerintah daerah lainnya, sesuai dengan kesiapan masing-masing. Sistem non-tunai ini dapat diterapkan secara bertahap oleh pemerintah daerah. Berikut akan dijabarkan mengenai keberagaman penerapan transaksi non-tunai pada beberapa pemerintah daerah di Indonesia:

\section{Keragaman Saat Dimulainya Implementasi Non Tunai}

Keragaman saat dimulainya implementasi nontunai di klasifikasikan menjadi: sebelum 2018, tahun 2018, tahun 2019 dan tahun 2020. Hasil yang didapatkan dari 73 pemerintah daerah yang dilakukan pendataan terdapat 10 pemerintah daerah menerapkan transaksi nontunai sebelum tahun 2018, 40 pemerintah daerah menerapkan pada tahun 2018 dan 23 pemerintah daerah menerapkan setelah tahun 2018.

Tabel 1. Tahun Impelementasi Non Tunai

\begin{tabular}{cccccc}
\hline $\begin{array}{c}\text { Pemerintah } \\
\text { Daerah }\end{array}$ & $\begin{array}{c}\text { Sebelum } \\
2018\end{array}$ & 2018 & 2019 & 2020 & Total \\
\hline Provinsi & 1 & 6 & 2 & 0 & 9 \\
Kota & 9 & 16 & 10 & 1 & 36 \\
Kabupaten & 0 & 18 & 10 & 0 & 28 \\
Jumlah & $\mathbf{1 0}$ & $\mathbf{4 0}$ & $\mathbf{2 2}$ & $\mathbf{1}$ & $\mathbf{7 3}$ \\
\hline
\end{tabular}

Data diolah oleh peneliti 2020

\section{Keragaman Implementasi Pemerintah Daerah di Pulau Jawa dan Luar Jawa}

Penerapan transaksi non-tunai di pemerintah daerah telah diimplementasikan pada pemerintah daerah di Indonesia. Penerapan ini dapat dikatakan merata pada seluruh pemerintah daerah di Indonesia. Klasifikasi ini dilakukan untuk melihat penerapan transaksi non-tunai pada pemerintah daerah berdasarkan lokasinya. Hasil penelitian menunjukkan bahwa penerapan transaksi nontunai diberlakukan untuk semua pemerintah daerah baik pada pemerintah daerah yang berada dipulau jawa maupun luar pulau jawa. Hal ini dapat dilihat dari tabel berikut:

Tabel 2. Penerapan Transaksi Non Tunai Berdasarkan Wilayah

\begin{tabular}{ccc}
\hline Pemerintah Daerah & Jawa & Luar Jawa/Bali \\
\hline Pemerintah Kabupaten & 8 & 20 \\
Pemerintah Kota & 13 & 23 \\
Pemerintah Provinsi & 4 & 5 \\
Jumlah & 25 & 48 \\
\hline
\end{tabular}

Data diolah peneliti 2020

\section{Keragaman Implementasi Berdasarkan Jumlah Transaksi yang telah di Non Tunaikan}

Berdasarkan jumlah transaksi yang telah dinontunaikan, implementasi transaksi non-tunai dilakukan pengelompokkan menjadi 3 kategori yaitu 1-5 transaksi, 1-10 transaksi dan full atau semua non-tunai. Pada penerapan transaksi non-tunai dilakukan secara bertahap baik untuk pendapatan maupun belanja. Contohnya pada pemerintah daerah Kota Padang melakukan transaksi non-tunai pada belanja perjalanan dinas dalam dan luar daerah, rapat koordinasi luar daerah, belanja makan dan minum dan belanja alat tulis kantor. Pemerintah Kabupaten pati menerapkan sistem non-tunai pada pembayaran gaji, honor, hibah, rekanan proyek, dan lainlain. Pemerintah daerah Kabupaten Cilacap melakukan penerapan transaksi non-tunai untuk seluruh transaksi non-tunai, baik untuk penerimaan maupun pengeluaran daerah. Hal ini merupakan lompatan yang luar biasa bagi pemerintah daerah Kabupaten Cilacap karena pada saat awal penerapan belum ada pemerintah kabupaten kota di Jawa Tengah yang menerapkan kebijakan transaksi nontunai mulai dari 1 rupiah tanpa ada yang dikecualikan.

\section{Keragaman Berdasarkan Batas Maksimal Penggunaan Transaksi Tunai}

Pemerintah daerah masih melakukan pembayaran dengan menggunakan sistem tunai. Hal ini masih diperbolehkan untuk dilakukan dengan nominal tertentu. Pembayaran dengan cara tunai diklasifikasikan mulai dari satu juta rupiah hingga diatas lima juta rupiah. Salah satu contohnya yaitu pada Pemerintah Kabupaten Banyuwangi yang memperbolehkan transaksi tunai sebesar Rp 5.000.000,- (lima juta rupiah) perharinya yang diatur dalam Perbup Banyuwangi No. 2 tahun 2018. Meskpun masih dapat melakukan transaksi tunai dalam melakukan pembayaran di pemerintah daerah, pada setiap periode masing-masing pemerintah melakukan peningkatan secara bertahap untuk penggunaan nontunai. Dimana setiap periode dilakukan pengurangan pembayaran tunai, sehingga kedepannya setiap pembayaran belanja dilakukan dengan non-tunai.

\section{Kendala Dan Manfaat Transaksi Non Tunai}

Pada penerapan sistem non-tunai ini, didapati hasil bahwa pemerintah daerah mengalami kendala dalam pelaksanaannya. Kendala yang dihadapi oleh beberapa pemerintah daerah dalam penerapan sistem non-tunai yaitu, software serta jaringan yang dimiliki oleh perbankan dan instansi belum memadai sehingga perlu dilakukan peningkatan agar lebih mudah digunakan. Infrastuktur yang kurang juga menjadi hambatan penerapan non-tunai sehingga perlu diberikan penambahan seperti laptop, komputer atau tablet khusus untuk bendahara atau staf bagian keuangan. Kurangnya pegawai yang berkompeten juga menjadi salah satu kendala yang banyak terjadi dimana pegawai atau staf keuangan kurang mengerti dengan sistem yang baru sehingga perlu dibekali dengan pelatihan dan sosialisasi.

Kendala lainnya yaitu kurang kuatnya komitmen pimpinan mengenai penerapan sistem ini. Setiap kepala daerah atau kepala dinas yang akan menerapkan sistem ini harus diiringi dengan pemberian pelatihan dan infrastruktur yang memadai. Tidak hanya asal 
menerapkan karena adanya aturan tetapi juga harus didukung dengan memberikan sarana dan prasarana yang cukup. Adanya rekan kerja dan pegawai yang tidak memiliki rekening yang sama dengan bank daerah yang bekerjasama dengan pemerintah daerah merupakan kendala lainnya yang dihadapi dalam penerapan sistem ini, sehingga perlu dilakukan pembukaan rekening untuk pihak-pihak yang berhubungan dengan pemerintah daerah untuk memudahkan urusan transaksi keuangan. Kendala yang dihadapi langsung yang berhubungan dengan masyarakat yaitu masih tingginya penggunaan pembayaran tunai di masyarakat. Perlu ditingkatkan kesadaran dan kepahaman masyarakat mengenai nontunai yang lebih memudahkan dalam bertransaksi dan lebih aman karena tidak perlu membawa banyak uang tunai. Selain itu juga perlu pemberian fasilitas untuk meningkatkan kesadaran masyarakat untuk menggunakan non-tunai seperti yang telah berjalan contohnya pembayaran pajak dengan non-tunai.

Selain kendala, tentu ada manfaat yang dirasakan pemerintah daerah dari penerapan sistem transaksi nontunai ini yaitu, meningkatnya pengendalian internal keuangan daerah serta mempermudah pemantauan/kontrol/penelusuran dana yang masuk dan keluar yang dilakukan oleh pegawai keuangan karena setiap kegiatan transaksi keuangan yang terjadi telah tercatat secara otomatis disistem keuangan yang baru yang berbasis digital. Manfaat lainnya yaitu penghematan anggaran karena tidak adanya transaksi tunai yang dapat menyebabkan pungli. Transaksi nontunai ini juga dapat mencegah peredaran uang palsu karena setiap kegiatan keuangan tidak menggunakan uang fisik secara tidak langsung juga dapat mencegah adanya transaksi ilegal atau korupsi. Sistem ini juga bermanfaat pada terwujudnya tertib administrasi pengelolaan kas dan juga bermanfaat pada ketepatan dan kecepatan dalam penyusunan laporan keuangan yang menjadi tepat waktu.

\section{SIMPULAN}

Pengelolaan keuangan daerah di Indonesia telah mengalami reformasi. Dampak dari adanya reformasi ini yaitu terciptanya paradigma-paradigma baru dalam pengelolaan keuangan daerah. Dimana paradigma baru yang terbentuk tentunya untuk mewujudkan pengelolaan keuangan pemerintah yang lebih baik. Kebijakan sistem transaksi non-tunai merupakan paradigma terbaru dalam pengelolaan keuangan daerah. Sistem transaksi nontunai merupakan langkah pemerintah dalam mewujudkan good governance. Dimana pemerintah dituntut untuk lebih transparan dan lebih bersih dalam mengelola keuangan daerah yang tentunya bertujuan untuk kepentingan masyarakat. Instruksi Presiden Nomor 10 Tahun 2016 dan Surat Edaran Menteri Dalam Negeri No 910/1867/SJ merupakan dasar hukum atau landasan dalam penerapan transaksi non-tunai pada pemerintah daerah. Penerapan sistem transaksi non-tunai di pemerintah daerah di Indonesia telah di terapkan diseluruh pemerintah daerah baik pemerintah daerah provinsi, pemerintah kota dan kabupaten baik itu dilakukan secara bertahap maupun secara keseluruhan pada setiap transaksi penerimaan dan pengeluaran dan juga pada waktu penerapannya. Kebijakan non-tunai telah diterapkan secara beragam di seluruh Indonesia. Dimana pada hasil penelitian menunjukkan bahwa waktu penerapan sistem non-tunai berbeda-beda pada setiap pemda. Penerapan sistem non-tunai menunjukkan hasil telah dilakukan oleh semua pemerintah yang ada di Indonesia. Pada penerapan sistem ini tidak semua transaksi langsung dapat dilakukan dengan cara nontunai. Sistem ini dilakukan secara bertahap sehingga pada pelaksanaannya masih dapat ditemukan transaksi tunai dengan nominal tertentu. Penerapan sistem transaksi non-tunai menghasilkan manfaat yang sesuai dengan prinsip-prinsip dari good governance.

\section{DAFTAR PUSTAKA}

Dona, Husna Rahma. 2018. Implementasi Pengelolaan Keuangan Dengan Transaksi Non Tunai Di Sekretariat Daerah Provinsi Sumatera Barat. Jurnal Ilmu Administrasi Publik. Vol. 1 No. 1.

Hendrawan, Suluh., Nur ANisah dan Lina Nasihatun Nafidah. 2019. Implementasi Transaksi Non Tunai Sebagai Dasar Tata Kelola Pemerintah Yang Baik: Studi Kasus Pada Pemerintah Kabupaten Jombang. Jurnal. Akuntabilitas Jurnal Ilmu Akutansi Vol. 12 (2).

Kurnia, Lidanna Dian. 2020. Analisis Efisiensi Penerapan Transaksi Non Tunai Dalam Pengelolaan Keuangan Daerah Pada Sekretariat Daerah Kota Metro Provinsi Lampung. Jurnal Manajemen Vol. 14 No. 1 April 2020. Issn 19786573.

Palantabirokrasi. 2017. Transaksi Non Tunai. Palantabirokrasi.blogspot.

https://palantabirokrasi.blogspot.com/2017/11/tran saksi-non-tunai.html

Petriella, Yanita. 2014. DKI Jakarta Jadi Model Transaksi Non Tunai. Jakartabisnis. rta.bisnis.com/read/20140815/77/250110/dki-

jakarta-jadi-model-transaksi-nontunai

Raharja, Ivan Fauzani dan Hafrida. 2017. Analisis Yuridis Penerapan Tata Kelola Pemerintahan Yang Baik Sebagai Upaya Pencegahan Tindak Pidana Korupsi Di Pemerintahan Daerah Kabupaten Sarolangun. Jurnal Sains Sosio Humaniora. Vol. 1 No. 2 Tahun 2017.

Septiani, Selly dan Endah Kusumastuti. 2019. Penerapan Transaksi Non Tunai Dalam Pelaksanaan Belanja Pemerinntah Daerah Untuk Mewujudkan Prinsip Good Governance (Studi Kasus Pada Badan Pengelolaan Keuangan dan Aset Daerah Pemerintah Provinsi Jawa Barat). 
Astri Tania Herlen, Vima Tista Putriana dan Denny Yohana, Implementasi Kebijakan Transaksi Non Tunai Pemerintah Daerah di Indonesia

Jurnal. Polban. Industrial Research Workshop and National Seminar.

Tee, Hock Han dan Hway Boon Ong. 2016. Cashless Payment and Economic Growth. Economics Unit, Faculty of Management, Multimedia University, Persiaran Multimedia, Cyberjaya, Malaysia.

World Bank. 1992. Governance and Development. Washington, DC: World Bank.

Yudhanti, Ashari Lintang. 2018. Penerapan Sistem Transaksi Non Tunai Terhadap Akuntabilitas Kinerja Manajerial. Behavioral Accounting Journal. Vol. 1 No. 2 e-ISSN: 2615-7004. 